\title{
As intelectuais Gabriela Mistral e Cecília Meireles nas bibliotecas infantis: traços da modernidade educacional no México e no Brasil
}

\author{
ROSÂNGELA VEIGA JÚLIO FERREIRA \\ Colégio de Aplicação João XXIII/UFJF, Juiz de Fora, MG, Brasil \\ HILDA APARECIDA LINHARES DA SILVA MICARELLO \\ Universidade Federal de Juiz de Fora, Juiz de Fora, MG, Brasil
}

RESUMO

Este texto discute projetos de formação do leitor com os quais as intelectuais $\mathrm{Ga}$ briela Mistral e Cecília Meireles se envolveram durante as reformas educacionais do México e do Brasil, respectivamente. Comparamos a trajetória de ambas as intelectuais no tempo histórico da modernidade educacional, por meio da análise das ações que fundamentaram a implementação de bibliotecas, em especial as destinadas à leitura pública das crianças. Atuaram na formulação de uma concepção de literatura infantil, defendendo a ideia de que escrever para criança exigia estudos detalhados sobre o gosto literário infantil, aliado à sensibilidade, deixando à geração que as sucedeu a possibilidade de dar continuidade ao que propuseram àquele tempo: formar a criança leitora.

PALAVRAS-CHAVE

Cecília Meireles; Gabriela Mistral; bibliotecas infantis; formação do leitor. 


\title{
THE INTELLECTUALS GABRIELA MISTRAL AND CECÍLIA MEIRELES IN CHILDERN' LIBRARIES: TRAITS OF EDUCATIONAL MODERNITY IN MEXICO AND BRAZIL
}

\begin{abstract}
The following paper debates projects of reader formation developed by the intellectuals Gabriela Mistral and Cecília Meireles during the educational reforms in México and Brazil, respectively. We analyzed both trajectories in the historical time of educational modernity, through the review of the actions that substantiated the implementation of libraries, in particular, the ones aimed at children's public reading. Acted on the formulation of a conception of childhood literature, defending the idea that writing to children demanded detailed studies about their literary liking, associate to sensibility, construing as legacy to the generation who succeeded the possibility to carry on what they proposed at that time: to form a child reader.

KEYWORDS

Cecília Meireles; Gabriela Mistral; library for children; reader formation.
\end{abstract}

\section{LAS INTELECTUALES GABRIELA MISTRAL Y CECÍLIA MEIRELES EN LAS BIBLIOTECAS DE LOS NIÑOS: CARACTERÍSTICAS DE LA MODERNIDAD EDUCATIVA EN MÉXICO Y EN BRASIL}

\section{RESUMEN}

Este texto analiza los proyectos de formación del lector que las intelectuales Gabriela Mistral y Cecília Meireles participaron durante las reformas educativas de México y Brasil, respectivamente. Comparamos las trayectorias de las intelectuales en el tempo de la modernidad educativa, mediante del análisis de la implementación de bibliotecas, en particular las destinadas a la lectura pública de los niños. Actuaron en la formulación de una nueva concepción de la literatura infantil, defendiendo la idea de que escribir para niños requieren estudios detallados sobre el gusto literario infantil, junto con la sensibilidad, dejando a la generación que sucedió a la posibilidad de continuar lo que propusieron a aquel tiempo: formar el niño lector.

PALABRAS CLAVE

Cecília Meireles; Gabriela Mistral; bibliotecas para niños; formación lector. 


\section{INTRODUÇÃO}

O objetivo deste texto parte dos resultados finais da pesquisa que resultou na tese de doutoramento Entre leitores, bibliotecas, campos e jardins: Gabriela Mistral e Cecília Meireles em projetos de educação popular no México (1920) e Brasil (1930) (Ferreira,2014), discutindo a concepção de leitura pública que as intelectuais ${ }^{1} \mathrm{Gabriela}$ Mistral e Cecília Meireles defenderam quando criaram bibliotecas nas décadas de 1920 e 1930, no México e no Brasil, respectivamente, comparando os movimentos ocorridos nesses países, identificando concepções de formação do leitor.

A metodologia utilizada foi a história comparada, por meio de uma análise documental, com base na hermenêutica ricoueriana e na história cultural. Investigamos os fatos que ocorreram na modernidade educacional com base em uma concepção de passado aberta a novas interpretações, analisando crônicas jornalísticas que versavam sobre educação ${ }^{2}$ e cartas que Mistral e Meireles trocaram entre si e com outros intelectuais na primeira metade do século $\mathrm{XX},{ }^{3}$ sustentando o que aqui chamamos de rede de referenciabilidades. ${ }^{4}$ A hermenêutica subsidiou a interpretação das experiências das intelectuais no contexto da modernidade educacional; a história cultural permitiu compreender os sentidos que advieram da dimensão afetiva das relações estabelecidas entre essas intelectuais.

Consideramos as contribuições da história cultural, no que se refere à rede de sociabilidades, como mais uma referência ${ }^{5}$ que, em articulação com outras, auxiliou

1 Adotamos, ao longo deste artigo, a acepção dada ao termo "intelectuais" pela própria Cecília Meireles, qual seja: alguém que consegue, ao olhar "as coisas do alto, vê-las em conjunto, ainda sem perder o encanto dos seus pormenores: contemplando o mundo como apartado dele, ama a variedade de ideias, sem se perder nos seus contrastes, com esse gosto, que só o pensamento universalista encontra, de ver emergir dentre as ondas contraditórias a realidade humana em sua figura completa” (Meireles, 1932a).

2 Analisamos crônicas jornalísticas produzidas por Meireles em 1930, na coluna Comentários, do jornal Diário de Notícias, e na década de 1940, na coluna Professores e Estudantes, do jornal carioca $A$ Manhã. Nas escritas por Mistral em vários jornais mexicanos, chilenos, norte-americanos e outros, o foco incidiu nas que versam sobre formação de leitor e nas que se referem a sua experiência no México. Para acessar crônicas de Meireles citadas neste artigo, consultar o site da Biblioteca Nacional do Brasil, e para as de Mistral, ver Zegers (2002, 2007).

3 Foram analisadas cartas que Meireles escreveu para Mistral, além das que trocou com a poetisa brasileira Henriqueta Lisboa e com o educador brasileiro Fernando de Azevedo, com o objetivo de identificar elementos que caracterizam aquele tempo histórico. No caso de Mistral, só analisamos uma resposta de Meireles, pois não foi possível contato com o acervo do Brasil. Analisamos também as que trocou com Henriqueta Lisboa e com o educador mexicano José de Vasconcelos, com o mesmo objetivo. Todavia, a referência a essas cartas não foi feita diretamente, dados os limites deste texto.

4 Esse conceito foi desenvolvido por Ferreira (2014) em tese de doutoramento.

5 Para Ricoeur (1995), a referência advém do jogo da compreensibilidade, da elaboração do sentido, em que o discurso narrativo vale-se de um duplo movimento: o que nos permite um afastamento do real, a configuração, e o que nos possibilita uma aproximação com o real, a refiguração, tendo como referência comum o mundo vivido como validação do real ou pretensão de verdade. 
na compreensão de como no campo intelectual as ideias de Mistral influenciaram o pensamento de Meireles, e vice-versa, identificando o que as une, as referenciabilidades que estabeleceram entre si e com outros intelectuais.

Defendemos que para compreender essa influência mútua é necessário perceber o sentido que se estabelece quando uma experiência é vivida a partir de referências comuns, compartilhadas pelo humano. Isso implica entender, nas cartas e crônicas, os laços geracionais, considerando percursos, contextos e outros elementos implícitos nesses textos. Gomes (1993, p. 65) aponta que "se os espaços de sociabilidade são 'geográficos', são também 'afetivos', neles se podendo [...] pensar uma espécie de 'ecossistema', onde amores, ódios, projetos, ideais se chocam, fazendo parte da organização da vida relacional”. Essa dimensão afetiva dos laços geracionais requer que se considerem experiências advindas dos lugares frequentados por ambas as intelectuais, atentando para o tempo e os sujeitos que neles circulavam, dialogando com uma ideia de tempo simultâneo e de duração, observando possíveis aproximações e/ou afastamentos. Não se trata da mera junção da contribuição de um e/ou outro campo teórico, mas do esforço de compreender laços geracionais de outro lugar: o da experiência como referência. Essa concepção acrescenta ao conceito de rede de sociabilidade, pautado na história cultural, a existência de lugares e relações, nos quais o solo comum (referência) seja comunicado e o sentido estabelecido.

Pensar o tempo histórico do acontecimento e a dimensão afetiva advinda do(s) lugar(es) em que esse acontecimento se manifestou permite compreender o processo de instituição dos laços geracionais. Laços que podem ser percebidos a partir dos sentidos que emergem dos diálogos que Mistral e Meireles travaram entre si e com seus contemporâneos, nos lugares que frequentaram, nos livros que leram e nos textos que escreveram. O entrelaçamento dessas ações e, simultaneamente, suas especificidades, constituem a rede de referenciabilidades, tecida de diversos campos da experiência humana: dimensões éticas, estéticas, sociais, educacionais, artísticas, políticas, entre outras.

Para situar a atuação de Mistral e de Meireles nos projetos educacionais ${ }^{6}$ que desenvolveram na modernidade educacional, faz-se importante aclarar o que compreendemos por tempo histórico em que situamos a concepção de modernidade educacional como inacabada. ${ }^{7}$ Em consonância com a hermenêutica ricoeuriana (Ricoeur, 2007), destacamos a temporalidade, condição fenomênica de percepção do tempo vivido, que se efetiva pelas marcações metodologicamente diferenciadas: cronometria, cronologia, cronografia e cronosofia.

6 Referimo-nos aos projetos de educação que advieram da Reforma Educacional mexicana da década de 1922, protagonizada pelo Secretário de Educação Pública José Vasconcelos, e da Reforma Educacional Brasileira administrada por Anísio Teixeira, quando atuou como Diretor Geral de Instrução Pública do Distrito Federal, no Rio de Janeiro, em 1931.

7 Rocha (2010) e Nunes $(2007,2009)$ elencam pontos diferentes para entender e polemizar o acontecimento da modernidade, apesar de ambos defenderem que se trata de um acontecimento inacabado, cujos dilemas ainda permanecem na contemporaneidade. 
As três primeiras dizem respeito à marcação cronológica propriamente dita. A cronometria associa-se à marcação cíclica, isto é, a que se repete indefinidamente — dia, semana, mês, ano. A cronologia é a marcação linear de períodos como século e milênio e que, portanto, não se repete. A cronografia diz respeito à percepção da passagem temporal pela sucessão de acontecimentos com marcação definida uns em relação aos outros. É o ponto de referência em uma narrativa, no caso deste texto, a modernidade educacional. Por último, a cronosofia diz respeito aos sentidos atribuídos aos acontecimentos cada vez que se vai a eles, percebendo-os como inacabados, permitindo, portanto, especulá-los, pesquisá-los, reinterpretá-los. O tempo histórico constitui-se, nessa concepção metodológica, em um jogo constante entre essas quatro dimensões.

A modernidade educacional é compreendida, então, como um tempo amorfo (Ricoeur, 2007), porque o sentido para esse tempo não está posto, determinado. Essa modernidade não é tomada apenas em sua circularidade - cronometria - ou em sua linearidade — cronologia. Interpretá-la é produzir um sentido novo para os acontecimentos a partir das imbricações entre cronografia e cronosofia.

Nas décadas de 1920 e 1930, as bibliotecas constituíam-se como instituições importantes para a formação dos leitores, devendo ocupar lugar de destaque nas políticas públicas. Nesse contexto, Mistral e Meireles estiveram à frente de projetos de educação que oportunizaram a organização de bibliotecas infantis, representando o novo no tempo histórico da modernidade educacional, à medida que conceberam a formação da criança leitora com base em novos paradigmas. Essas concepções trouxeram reflexos na produção literária específica para o público infantil.

No âmbito de seus projetos de formação da criança leitora, Mistral e Meireles buscaram um lugar para a criança na sociedade, entendendo escola e bibliotecas como instâncias privilegiadas de formação. Essas intelectuais defendiam a necessidade de uma modificação no tratamento e na forma de entender essa criança, tendo em vista seu protagonismo na sociedade, rompendo com uma tradição que a via como ser sem autonomia de pensamento.

A infância é concebida neste texto como uma questão geracional (Ricoeur, 2012), ${ }^{8}$ na medida em que se trata de um tema abordado nas gerações que antecederam àquela de Mistral e Meireles. Para além de uma etapa da vida humana, a infância é compreendida como uma categoria histórica, para a qual diferentes épocas e sociedades produzem sentidos também diversos.

Mistral e Meireles empreenderam movimentos que contribuíram para problematizar a infância como "vir a ser" quando conferiram às crianças o estatuto de sujeito, entendendo-as como leitores capazes de interpretar o mundo, sendo necessário atentar para essa concepção ao produzir literatura infantil. As intenções que as duas intelectuais preconizaram em sua geração, em virtude das questões que

8 A ideia geracional remete a um pensamento de continuidade. Isso significa que as gerações, a despeito de serem distintas, tangenciam-se, sobrepondo-se. 
emergiram do contexto que caracterizou a modernidade educacional, é ainda hoje um projeto desafiador: a formação de leitores. A atualidade desse desafio sustenta a ideia de inacabamento da modernidade educacional.

Por essa concepção, analisamos as bibliotecas latino-americanas sob a égide do tempo histórico, considerando transformações que ocorreram no mundo e que influenciaram os projetos de constituição de bibliotecas no México e no Brasil. A atualidade das discussões que se colocaram no tempo de nascimento dos projetos de educação desses países aponta para a necessidade de entender e comparar mudanças educacionais que interferiram na forma como bibliotecas foram concebidas. $\mathrm{E}$, por consequência, como tais mudanças se desdobraram, para cada uma dessas escritoras, na efetivação de ideias e em utopias compartilhadas.

Cotejamos o que ocorreu na educação do México, na década de 1920, e no Brasil, na década de 1930. A exigência da questão histórica como medida de comparabilidade coloca-se como possibilidade de superar a insuficiência que uma comparação de variáveis e invariáveis, semelhanças e dessemelhanças poderia fornecer. Ao comparar os contextos das reformas educacionais dos dois países, identificam-se componentes fixos (Schirewer, 1997) que realçam e captam problemas, que permitem identificar convergências, divergências e contrastes no modo como tais problemas foram tratados em ambos os países.

Comparam-se México e Brasil porque ambos os países viveram o mesmo tempo histórico da modernidade educacional que colocou, de maneira imperativa, questões como o acesso à escolaridade obrigatória, o protagonismo do Estado com relação a esse acesso e a exigência orçamentária que ele demanda. Os dois países compuseram esse momento da transformação histórico-jurídico-política na constituição do direito social à educação.

Antes de aprofundarmos o tema do pensamento educacional de Mistral e Meireles, cabe salientar que, mesmo impossibilitadas de fazermos ponte direta entre diferentes épocas, dadas as especificidades dos tempos históricos, constatamos que as intelectuais foram herdeiras de concepções acerca da infância que coexistiram na geração em que viveram, como a iluminista, as quais rechaçaram ou com as quais dialogaram. Por isso retomamos alguns estudos específicos sobre o tema para pensar a criança e seu lugar em diferentes tempos.

As obras desses cânones da literatura estão presentes em escolas latino-americanas e seus discursos políticos em cursos de formação de professores. Isso nos leva a indagar: se elas conceberam bibliotecas para crianças, a partir de um projeto de formação de leitores que ainda hoje perseguimos, em que momento de suas trajetórias o tratamento desse tema central colocou-se como proeminente e em que momento se perdeu? Procuramos elencar, ainda no que se refere a este último ponto, alguns dos prováveis motivos de ainda perseguirmos o que ambas idealizaram no que se refere à formação da criança leitora.

Para entender por que idealizaram e organizaram bibliotecas especialmente para as crianças, apresentamos concepções que nortearam a defesa das intelectuais Gabriela Mistral e Cecília Meireles nos debates do tempo em que atuaram em esferas públicas dos campos literário, jornalístico e educacional. 


\section{GABRIELA MISTRAL E A LEITURA PARA CRIANÇAS: DESAFIOS DE UMA GERAÇÃO}

Lucila Godoy Alcayaga ${ }^{9}$ nasceu na cidade chilena de Vicuña, em 1889, vindo a falecer em 1957. No início do século XX, começou a trabalhar como professora primária, ganhando renome. No ano de 1945, recebeu o Prêmio Nobel de Literatura, sendo a primeira mulher latino-americana a adquirir tal premiação.

Gabriela Mistral demonstrou preocupação com as crianças tanto nos seus escritos quanto no trabalho dedicado ao magistério. Nos livros que publicou havia um lugar destinado às crianças, e alguns deles foram escritos especialmente para esses leitores.

Divulgou, em diferentes periódicos, a necessidade de critérios, ao mesmo tempo rígidos e flexíveis, ao escrever para crianças. Rígidos, no que se referia à disciplina necessária ao enfrentamento de tal desafio; flexíveis, por ser importante abrir-se para os significados que as crianças atribuíam para os livros que liam.

Evidenciamos nesse discurso a ideia de que às crianças deveria ser oportunizado o contato com uma literatura que as provocasse a pensar sobre suas experiências no mundo, entendendo o que poderia emanar do imaginário infantil, ainda que a seleção pelo adulto dos livros considerados adequados demonstrasse que essa infância precisava ser protegida das mazelas sociais.

Mistral concebe a criança simultaneamente como ser de natureza e de cultura, sem dicotomizar essas dimensões humanas. Por isso seu projeto de formação de leitores incluía a oferta de livros às crianças que viviam no campo, e não apenas àquelas que frequentavam as escolas urbanas. Defendia que "el niño criado en el campo entra en la ciudad conun capital de salud; lleva todas sus facultades vivas y ricas, y posee dos virtudes profundas, que son las del campesino en todo el mundo: la fuerza e la serenidad, que emanan de la tierra y del mar" (Mistral, 1924 apud Zegers, 2007, p. 140).

Mistral afirmou reiteradamente, nos discursos jornalísticos, que os livros previamente selecionados pelos adultos precisavam circular pelas mãos das crianças tanto nas escolas como em suas casas, referindo-se à necessidade de empréstimos de livros pelas bibliotecas públicas e escolares. Sua defesa era também pelo que denominou de livros ambulantes, pois acreditava ser necessário que, no caso da reforma mexicana de 1922, os livros saíssem "de la capital, en grandes camiones llenos de libros, de herramientas agrícolas de semillas. [...] Van adentrándose lentamente, pasan pequeñas ciudades, divulgando[la buena nueva" (Mistral, 1926a apud Zegers, 2007, p. 175). Além disso, definiu em cartas que trocou com José Vasconcelos ${ }^{10}$ a importância de que a leitura fosse valorizada com os moradores do campo.

9 Lucila Godoy Alcayaga foi premiada em sua terra natal, em 1914, com uma alta condecoração - Flor natural, medalla de oro y corona de laurel (Mistral, 1962, p. VI) - pela produção poética de Los sonetos de la muerte. Foi por essa ocasião que passou a usar o pseudônimo de Gabriela Mistral.

10 O intelectual apontado nesse parágrafo e outros citados no corpo deste artigo são expoentes do contexto intelectual e educacional das décadas de 1920 e 1930, no México, no Brasil e em outros países, que dialogaram com Mistral e Meireles. Para maior detalhamento acerca desses diálogos, consultar Ferreira (2014). 
Constatou, quando acompanhou algumas das missões de difusão do livro às populações campesinas, que "el abandono en que los ha tenido el centro. Dicen sus necesidades: caminos, tierra, herramientas, buena justicia rural y maestros que los comprendan; nada más" (Mistral, 1926a apud Zegers, 2007, p. 175). Mistral e Vasconcelos defendiam que o maior número possível de mexicanos deveria ter acesso à leitura, entendida como ação a ser exercida pelo Estado.

Durante as viagens que fez ao interior mexicano, constituindo-se como mais uma divulgadora da reforma educacional em curso no México, Mistral proferia palestras para orientar moradores do campo sobre o papel do livro na formação da criança, explicava como os próprios camponeses poderiam construir suas escolas. Em que pese saber ser papel do Estado prover essa necessidade, entendia, tal qual escreveu quando estivera envolvida com questões educacionais chilenas, que a sociedade também deveria participar desse processo de desenvolvimento do país pela ampliação da educação. Divulgou, em uma de suas crônicas jornalísticas, parte desse discurso, que convidava a população a construir escolas para atender à formação das crianças do campo, sem perder de vista a constituição de uma biblioteca: "la escuela se levanta, aprenderán Uds. a leer, plantando los árboles o en una capacitada escuela [...]. En la tarde de los sábados, les haremos la lectura comentada; hemos traído una biblioteca formada de obras sencillas" (Mistral, 1926a apud Zegers, 2002, p. 175).

Para Mistral, a formação da criança leitora é concebida em diálogo com o contexto de vida das crianças do meio rural, no âmbito de uma valorização da cultura do homem do campo em suas mais diferentes manifestações, sendo esta uma peculiaridade de seu projeto de formação de leitores: as bibliotecas devem ir ao encontro dos leitores em potencial.

A concepção de Mistral de que deveria ser oportunizado às crianças o acesso ao livro que respeitasse as especificidades do universo infantil era e ainda é um grande desafio. Os reflexos e as refrações dessa defesa de Mistral, em prol de uma criança que precisa ter sua autonomia reconhecida, justificam a reedição de suas obras literárias. Na mesma linha, a compilação de seus textos educacionais e crônicas jornalísticas, assim como a perpetuação de seu nome em monumentos, museus, bibliotecas, escolas e outros espaços de educação e cultura, em diferentes países latino-americanos, evidenciam o reconhecimento de seu papel na cena educacional.

\section{CECÍLIA MEIRELES E A LEITURA PARA CRIANÇAS: DESAFIOS DE UMA GERAÇÃO}

Cecília Benevides de Carvalho Meireles nasceu no Rio de Janeiro em 1901, vindo a falecer em 1964. Iniciou seus estudos na Escola Estácio de Sá, passando depois para o Instituto de Educação do Distrito Federal (Rio de Janeiro), onde se formou normalista em 1917, aos 16 anos.

A criança leitora foi tema recorrente em seus discursos. Exortou autores a atentarem para a relevância e urgência de uma literatura dedicada às crianças. Ela própria produziu literatura infantil e proferiu palestras com o intuito de sensibilizar professores para a necessidade de que leituras para crianças ocupassem um lugar especial nas escolas. 
Apesar de ter afirmado em suas crônicas que diferentes instituições, além da escola, concorriam para educar a criança e que a educação popular precisava ser valorizada, identificamos em seus discursos uma centralidade das bibliotecas escolares como espaços que possibilitariam o contato com práticas e valores oriundos de nossa herança matizada pela influência europeia, que dá voz aos nossos colonizadores. Trata-se de uma valorização da cultura erudita, expressa, por exemplo, na tradução de peças teatrais belgas e espanholas, cuja divulgação nas escolas entendia ser importante.

Percebemos na defesa de Meireles uma proposta de formação do leitor que o concebe como aquele que precisa receber "as luzes" do saber erudito. Tal proposta retoma a tradição da geração iluminista da qual foi herdeira e representa a valorização do saber considerado válido socialmente. Por vezes escreveu trechos em francês ou em espanhol, tanto na coluna jornalística destinada à educação do Diário de Notícias quanto na do jornal $A$ Manhã, utilizando-se desses veículos de informação para defender a formação de um leitor erudito. A despeito dessa valorização da erudição, por mais de dois anos divulgou, no segundo veículo midiático, cantigas e contos do interior do Brasil, sem, contudo, abandonar os que compunham o folclore da França ou da Espanha, por exemplo. Percebemos, portanto, uma tensão no discurso de Meireles, que transita pela ideia de que era importante valorizar a cultura do povo, entendendo-a como a cultura do lugar, e aquela de valorização de uma cultura erudita, de caráter universal.

Ao assinar o Manifesto dos Pioneiros da Escola Nova, ${ }^{11}$ Meireles corroborou com um ideário educacional que defendera de forma veemente nas páginas do Diário de Notícias, na década de 1930, no qual o tema central foi a educação popular na Reforma de Anísio Teixeira no Distrito Federal. Divulgou e materializou esse pensamento da Escola Nova não só nos discursos jornalísticos nos quais defendeu a concepção de criança presente no referido manifesto, mas também quando organizou a biblioteca infantil Pavilhão Mourisco.

A concepção de infância presente no Manifesto dos Pioneiros e em seu discurso era a de criança como um ser belo e generoso - pensamento herdado da geração iluminista. A essa criança a escola deveria satisfazer as necessidades e favorecer o intercâmbio de experiências que a levassem ao trabalho, uma vez que "convém aos seus interesses e às suas necessidades" (Azevedo, 1932, s/p), a quem deve ser proporcionado o contato com o ambiente ao seu entorno "para que [os adultos] possam, desta forma, possuí-la, apreciá-la e senti-la de acordo com as aptidões e possibilidades" (Azevedo, 1932, s/p), preparando-a para o trabalho e para vida. Dessa forma, a escola teria a responsabilidade de articular conhecimentos científicos e técnicos com a arte, a literatura e os valores sociais. Todas as vezes em que o discurso de Meireles recaía sobre uma modernidade educacional pensada na e pela escola, especialmente para uma criança que precisava ser protegida das mazelas sociais, tal qual Mistral, aproximava-se do que considerou um momento ímpar da história da educação brasileira — o Manifesto dos Pioneiros da Escola Nova.

11 O Manifesto dos Pioneiros da Escola Nova, documento assinado por vários intelectuais vinculados à Associação Brasileira de Educação, apresentava os ideais educacionais que deveriam pautar a escola no contexto da modernidade educacional. 
Cecília Meireles defendeu, de forma reiterada, que era necessário que a criança se comunicasse com o "universo que está nos astros e nos planetas e nos olhos maternos, em que adormece o conhecimento silencioso do segredo da vida" (Meireles, 1932b, p. 6), ou seja, sonhasse, viajasse, se enriquecesse e ao outro com suas experiências. Acreditava que o livro não podia limitar a vida em pequenos aspectos, ao contrário, deveria "deixar a sua forma integral que só integral satisfaz, como alimento humano"(Meireles, 1932b, p. 6). A leitura deveria, então, impulsionar as crianças a novos horizontes, alimentando-a.

Essa mesma ideia da leitura como fonte de alimento serviu de mote para Meireles propagar, em sua faceta jornalística, a preocupação com a qualidade dos livros infantis, amplamente divulgada em esferas públicas, e que marcou seu discurso centrado na busca por um lugar para a criança na literatura. Defendia, de forma veemente, a importância de uma atitude ética necessária aos autores de livros infantis que revelava a concepção de que escrever para crianças implicaria, necessariamente, unir arte e ciência. Arte, na medida em que um texto pensado para as crianças não determinaria limites à imaginação. Ciência, por considerar as especificidades da infância, entendendo a criança como uma leitora capaz de ultrapassar paradigmas, quando impulsionada por uma leitura curiosa do mundo que a cercava. Formar a criança leitora constituiu-se como um dos compromissos de Meireles, para quem era necessário que aqueles que escrevessem para as crianças as percebessem "com elevação e inteligência" (Meireles, 1930), concebendo-as como sujeitos com autonomia de pensamento.

Tal autonomia, entretanto, apresenta-se matizada pela preocupação de proteção das crianças daquilo que as deseducava. Sempre que possível, Meireles escrevia na coluna Comentários, do jornal Diário de Notícias, sobre os livros infantis lançados no Brasil e no exterior. Crítica, estava atenta ao percurso empreendido pelos escritores ao escreverem para esses leitores e reforçava a importância de que esses livros instigassem o imaginário da criança, considerando a linguagem e as ilustrações. ${ }^{12}$

O cuidado presente na seleção dos livros infantis e na constituição do espaço para que essa literatura pudesse se consolidar, valendo-se da opinião literária das crianças, apontava para uma concepção de infância envolta em pureza e na riqueza própria a essa fase da vida. A tensão entre uma concepção de criança capaz de produzir sentido para suas experiências no mundo e aquela de um sujeito a ser moldado pela vontade do adulto também atravessa a produção literária de Meireles voltada ao público infantil. Na década de 1910, produziu uma obra literária com uma perspectiva moralizante (Fernandes, 2008). Trata-se da obra Criança meu amor, que foi adotada pela Diretoria Geral de Instrução Pública do Distrito Federal (Lôbo, 2010). ${ }^{13}$ Nesse livro a criança aparece como ser dócil e que deveria obedecer aos adultos da família e aos de outras instâncias sociais, como a escola.

12 Além de analisar os livros de Monteiro Lobato, fizeram parte da sua atuação como crítica literária as obras do argentino Constâncio C. Vigil entre outros escritores nacionais e estrangeiros.

13 De acordo com Lôbo (2010), as obras Romanceiro da Inconfidência (1953) e Rui: pequena história de uma grande vida (1949 - edição comemorativa do centenário de Rui Barbosa) são de cunho pedagógico. 
Quase duas décadas depois, essa perspectiva moralizante da literatura voltada para a criança ganhou contornos diferentes na obra literária de Meireles. Resultado, a nosso ver, do próprio processo de interação com intelectuais brasileiros representantes do movimento da Escola Nova, como Anísio Teixeira, Fernando de Azevedo, Armanda Álvaro Alberto, Noemi Silveira, entre outros. Além desses, destacamos o encontro com a educadora francesa Mme. Artus Perrelet, que veio da França ministrar um curso sobre a importância do desenho na educação das crianças na Escola de Aperfeiçoamento em Belo Horizonte ${ }^{14}$ e, na sequência, no Distrito Federal (Rio de Janeiro), e outros literatos infantis, entre eles, Mistral, que Meireles constantemente citava no Diário de Notícias, na Página de Educação, que dirigia, sustentando a ideia de uma literatura específica para as crianças. Nesses encontros, veio instituindo uma rede de referenciabilidades, estabelecendo diálogos com seus pares em cartas, o que se traduziu em uma defesa da necessidade de que a educação das crianças ocupasse o cenário político e educacional de seu tempo. Como uma das protagonistas desse momento político, Meireles escreveu para crianças e sobre crianças, discursando sobre a importância de que os adultos criassem estratégias para ouvi-las, deslocando-se dos seus lugares de saber para interpretar as necessidades da infância.

Com um discurso que reiterava o papel do livro e da leitura na formação integral da criança, Mistral e Meireles conceberam bibliotecas infantis que deveriam suscitar, antes de qualquer outra, a dimensão afetiva dos leitores, protegendo a infância de leituras que, em suas opiniões, fossem nocivas ao desenvolvimento infantil, porém, ao mesmo tempo, fomentando as capacidades criativas da criança e as diversas manifestações dessas capacidades. Nessa concepção, a leitura pública é fonte e tema de sustentação das bibliotecas infantis mexicanas e brasileiras, rompendo com a ideia de uma literatura simplesmente moralizante.

\section{A BIBLIOTECA INFANTIL MEXICANA: UM PROJETO DE FORMAÇÃO DO LEITOR}

Quando atuou como diretora do Liceo de Niñas no Chile, em 1918, Gabriela Mistral considerou a organização da biblioteca de duas formas: adaptando de parte do espaço físico, originalmente projetado para adultos, com o objetivo de atender momentos de leitura para as crianças; e rompendo com a ideia de um espaço fixo para a biblioteca, possibilitando que o livro circulasse por diferentes lugares da cidade, promovendo momentos de interação por meio de um amplo acervo. Percebemos que essa concepção de formação do leitor esteve presente no processo de (re)estruturação das bibliotecas mexicanas durante a Reforma de $1922 .{ }^{15}$

Como exemplo de adaptação do espaço físico da biblioteca no México, é possível constatar a preocupação com a presença de uma sala de leitura e de um

14 A criação da Escola de Aperfeiçoamento (1929-1946) foi uma decorrência da Reforma do Ensino Primário e Normal do governo do estado de Minas Gerais (1927-1928).

15 Sobre as bases que estruturaram a Reforma Mexicana de 1922 em três departamentos - Escolar, Belas-Artes e Bibliotecas - , sendo este último organizado em diferentes modalidades de biblioteca, consultar Ferreira (2014). 
acervo literário especialmente criado para as crianças nas bibliotecas públicas e nas escolares. No que se refere ao espaço compartilhado entre adultos e crianças, temos como exemplo as bibliotecas circulantes, cujo acervo literário foi pensado para diferentes leitores que circulavam por cidades mexicanas.

Apresentamos, na Figura 1, o exemplo de uma biblioteca infantil que representava a concepção defendida por Mistral desde sua atuação no Chile. A foto data do ano de 1923, no auge da gestão de José Vasconcelos, quando a chilena atuava diretamente com o mexicano no intuito de dar forma ao projeto educacional da Reforma Mexicana de 1922. Livros. Estantes. Desenhos nas paredes. Cadeiras. Mesas. Adulto. Crianças. Partes de um cenário que apontava, a nosso ver, para uma concepção de educação que tinha na ocupação de um espaço público de leitura a possibilidade de se formar como leitor, isso porque, a partir da ampliação do acesso à leitura dirigida pelo adulto, que supervisionava o acesso ao livro, era possível ampliar as experiências leitoras.

Dessa fotografia destacamos, em especial, as pinturas das paredes, que remetem à presença de elementos que aproximam as crianças do ambiente, assim como o fato de alguns livros ficarem em uma altura suficiente para que os próprios estudantes pudessem pegá-los.

O mesmo acontecia com o Centro Cultural Pavilhão Mourisco, organizado por Meireles. Nessa biblioteca percebemos que também era possível às crianças escolherem os livros, mas dentro de um universo previamente selecionado, com o objetivo de manter a moral, os bons costumes e o espírito de pertencimento ao país. Que livros essas crianças estavam lendo não há como precisar pela pesquisa que fizemos. O que

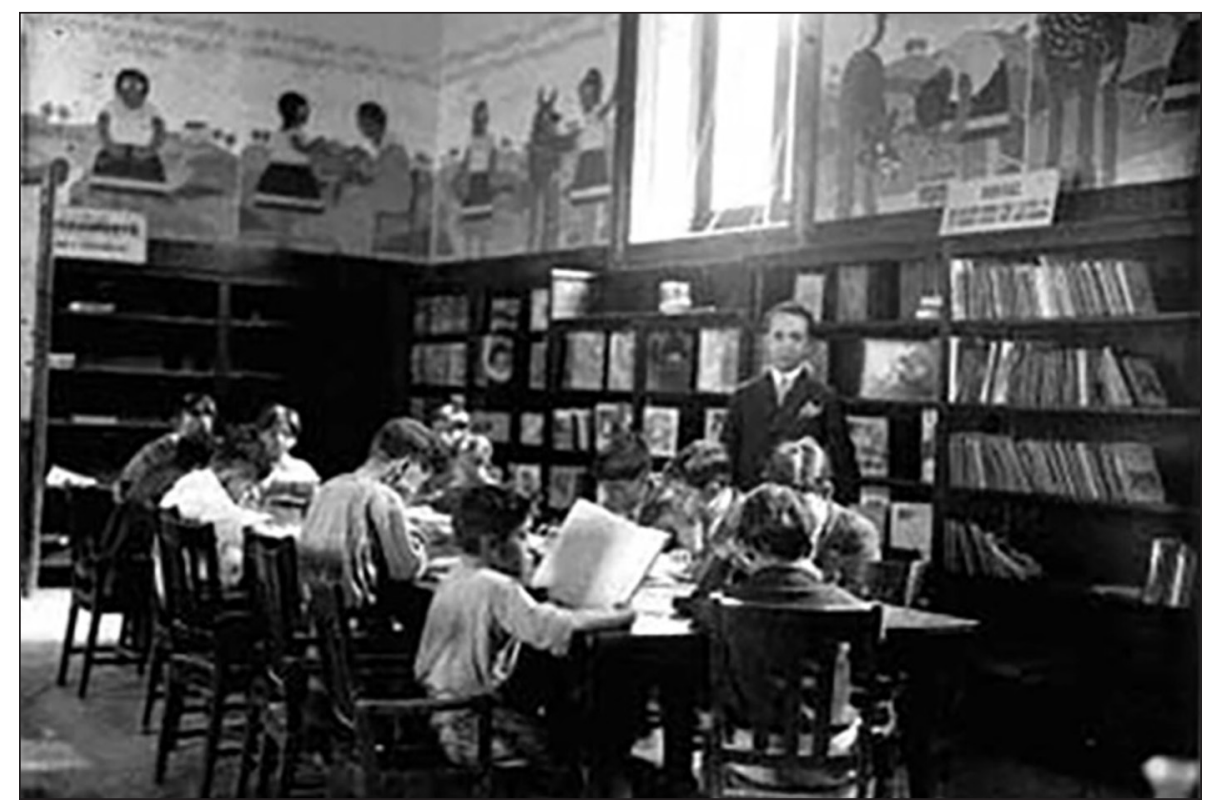

Figura 1 - Biblioteca infantil mexicana

Fonte: <http://www.miaulavirtual.com.mx/ciencias_de_la_informacion/Bibliotecas_Mexico/Biblioteca_Jose_Vasconcelos. htm>. Acesso em: 17 nov. 2012. 
podemos afirmar é que a preocupação era de que cada vez mais crianças tivessem acesso a livros. As bibliotecas, no caso as infantis, deveriam oportunizar o acesso ao patrimônio público - livro - que contasse a história de outros tempos, sendo responsabilidade do Estado também possibilitar a instrução com "livros adequados" que contariam a história do novo tempo. Tais livros, considerados adequados pelo poder público, materializavam escolhas que refletiam concepções de época.

Percebemos que os estímulos do espaço foram cuidadosamente planejados, representando, pelo que observamos na Figura 1, uma ruptura com os modelos de biblioteca que vigoravam antes da atuação de Vasconcelos, na Secretaria de Educação Pública (SEP). De acordo com as informações apresentadas na referida figura, naquele espaço "los niños conviven con el conocimiento contenido en los libros y la inspiración convocada por las artes plásticas y literarias. Esta biblioteca sintetiza la utopia cultural de quien fuera ministro de Educación en México de 1920 a 1924: José Vasconcelos". ${ }^{16}$

Apesar da ideia de os alunos e professores estarem possivelmente "posando" para as fotos, especialmente no caso da Figura 2, entendemos que essa imagem, divulgada pelo Boletin de la SEP, evidenciava o que Mistral defendia, conforme se pode observar.

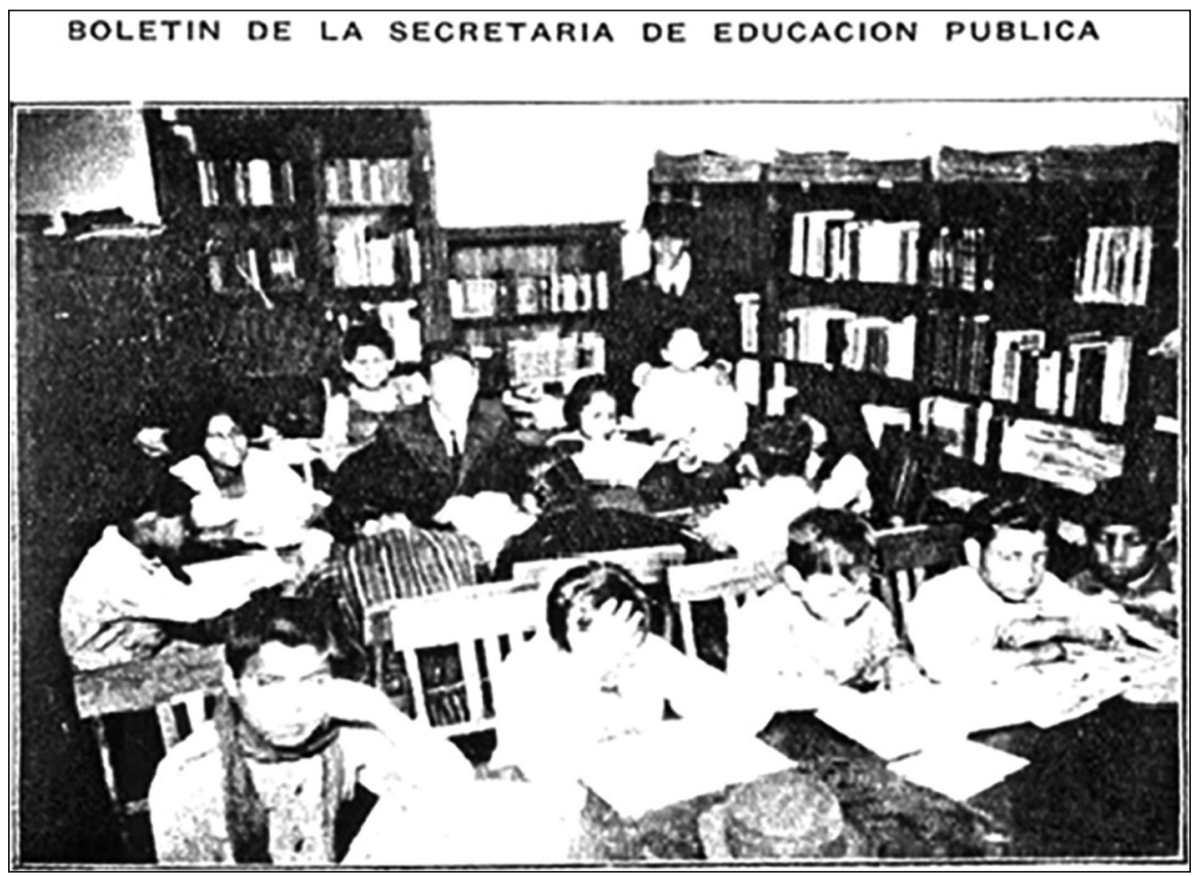

Figura 2 - Aspectos da Biblioteca Gabriela Mistral

Fonte: Zegers (2007, p. 212).

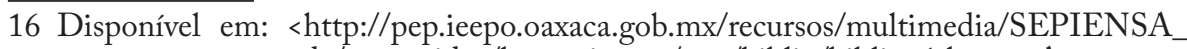
conectate_y_aprende/contenidos/h_mexicanas/s.xx/biblio/biblio_1.htm >. Acesso em: 10 jan. 2014. 
Nesse caso, referimo-nos ao fato de que às crianças e aos adultos deveria ser facultado o acesso à leitura. $\mathrm{E}$, no que diz respeito às crianças, uma leitura mediada pela presença de um adulto. $\mathrm{Na}$ Figura 2 há um adulto, inclusive, sentado entre as crianças e, assim como na Figura 1, os livros encontram-se próximos a essas crianças. A despeito das dificuldades e entraves de implementação de bibliotecas, Mistral insistia na importância dessa instituição, especialmente porque acreditava, conforme dito de forma reiterada em seus discursos jornalísticos, que "ella puede salvar a los hombres de la cantina mal oliente y librar a los chiquitos de la jugaretta en la vía pública" (Mistral, 1950 apud Zegers, 2007, p. 316).

Entendida como complementar à biblioteca fixa, a biblioteca circulante, na qual o leitor pegava os livros e ora os lia ao ar livre ou no interior das salas de leitura, ora realizava empréstimos, representava uma das ações do Departamento de Bibliotecas considerada por Mistral uma maneira de aproximar tanto o adulto quanto a criança do livro (Figura 3). As estantes baixas, possibilitando o acesso direto, assim como a disposição ao ar livre ilustravam a concepção de livro e de biblioteca que norteou as ações de formação da criança leitora na década de 1920 no México: a luta em benefício de uma leitura pública de massa, quer seja no campo, quer seja na cidade, por meio de uma literatura que atendesse aos interesses do público que frequentasse praças, clubes, jardins. Nesse caso, havia uma preocupação com a circulação do acervo por meio das entregas feitas pelos professores ambulantes, entendido como aquele que levava os livros até os leitores.

Percebemos que o plano da leitura rural mexicana encontrava caminhos nas bibliotecas circulantes, embora a operacionalização tenha desafiado os políticos a

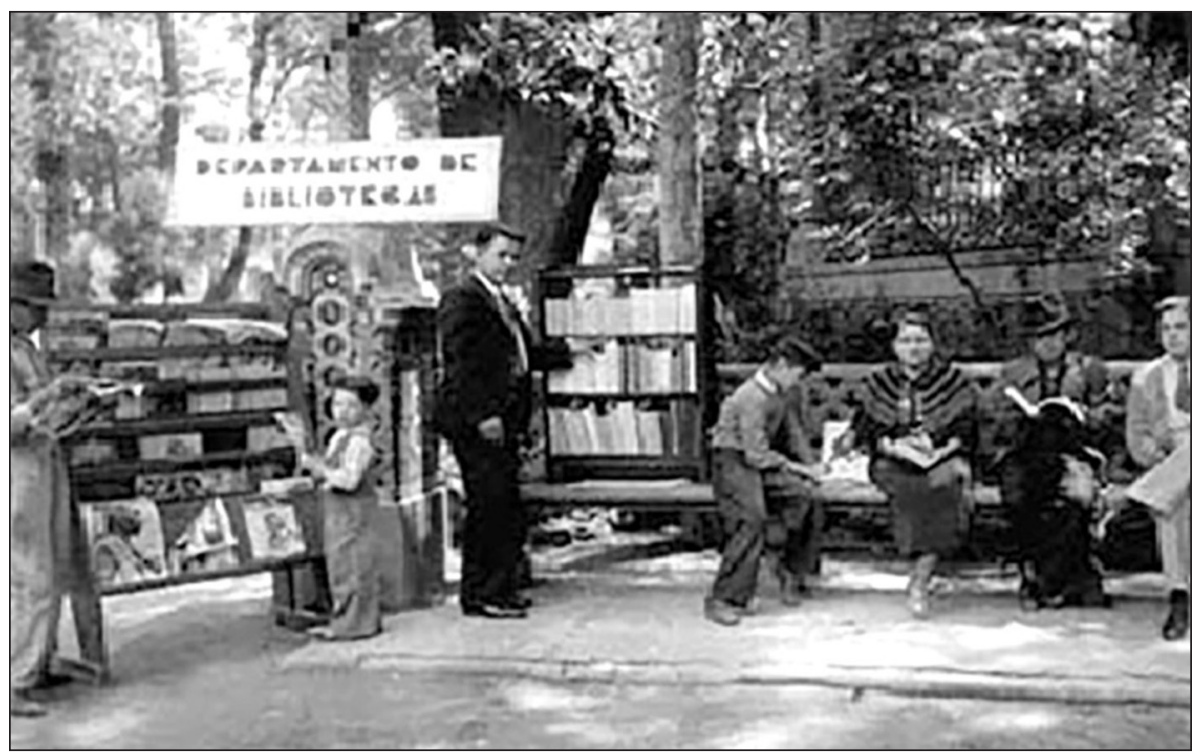

Figura 3 - Biblioteca circulante

Fonte: $<$ http://www.miaulavirtual.com.mx/ciencias_de_la_informacion/Bibliotecas_Mexico/Biblioteca_Jose_Vasconcelos. $\mathrm{htm}>$. Acesso em: 17 nov. 2012. 
criar estratégias para o seu bom funcionamento. Nas avaliações da SEP da década de 1920, de acordo com Fell (1989), era preciso ter mediadores, visitar o maior número possível de lugares e ter verba para manter acervo em constante mudança.

Apesar de ser difícil avaliar os resultados das campanhas de acesso ao livro oriundas da Reforma no México, a criança que aparece com o livro aberto, podendo folheá-lo e escolhê-lo com certa autonomia, conforme pode ser interpretado pela observação da Figura 1, representa a concepção de leitor que Mistral defendia. Tratava-se de um leitor que deveria ser estimulado a ler uma literatura considerada adequada, conforme discutido quando nos referimos ao processo de escolha dos chamados "livros bons".

No que se refere à biblioteca circulante, apresentada na Figura 3, trata-se da realização de um ideal educacional democrático de acesso à leitura. O que identificamos nessa imagem é a preocupação de quem organizou o espaço dessa modalidade de biblioteca para que fosse proporcionado às pessoas que dela se aproximassem um ambiente aconchegante, propício à leitura.

Vasconcelos tinha clareza da necessidade de que a literatura infantil fosse pensada em suas particularidades e que seu país carecia de livros que abarcassem o universo da criança. $\mathrm{Na}$ tentativa de atuar no intuito de minimizar essa carência, elaborou uma coleção com o objetivo de formar leitores com referências canônicas da literatura universal adequadas às crianças. Foi com essa iniciativa que o intelectual mexicano iniciou o trabalho editorial infantil na SEP, tendo como meta oportunizar às crianças mexicanas "una visión panorâmica ordenada en el tiempo, así como poner los en contacto con los más belos sucesos, los mejores ejemplos y las más 1la mativas ficciones que han producido los hombres" (Lombardo García, 1997, p. 91 ). ${ }^{17}$

Como os livros escolhidos para compor as diferentes modalidades de biblioteca, em especial a infantil, deveriam fortalecer a nacionalidade, além da presença dos clássicos europeus traduzidos, os livros infantis deveriam ser de autores hispano-americanos, podendo conter ainda os que fossem de autoria de outras línguas originárias do latim e das populações indígenas locais. Esse critério de escolha corrobora uma concepção de criança como um "vir a ser", ou seja, a modernidade educacional colocava para a educadora chilena a necessidade de pensar no fortalecimento da nação mexicana também pela via da leitura. As leituras previamente selecionadas deveriam formar o "adulto de amanhã", que seria responsável pelo crescimento econômico e pela valorização cultural do país. Tratava-se de uma escolha consciente de quem sabia o poder que a leitura teria para o fortalecimento do país. Em que pese o fato de esse pensamento ter sido influenciado pelo ideário iluminista, Mistral também entendia a leitura como um espaço de produção de significados no qual a criança não seria um ser passivo.

Para tal, tanto Vasconcelos quanto Mistral incentivavam a população para que escrevesse livros em que a cultura do povo pudesse ser divulgada. Vasconcelos, por meio da SEP, passou a estimular a produção dessas edições com o objetivo de reduzir ao máximo os custos, sendo o responsável por editar não só esses livros

17 O primeiro volume do livro Lecturas clásicas para niños contava com clássicos orientais, gregos e os da Antiguidade. No segundo circulavam histórias que narravam a memória, a história e a cultura do México (México, 1924a, 1924b). 
como também "leyendas celebres del Oriente y el Occidente, de Europa y aun de la America pre colombiana" (Vasconcelos, 2002, p. 86). O que o mexicano preconizava era que tais traduções não se constituíssem como meras reproduções do pensamento anglo-saxão, mas que, de alguma forma, pudessem retratar também a realidade dos povos que compunham a população mexicana, possibilitando uma visão global da literatura, o que não foi tarefa fácil. Nas palavras do próprio Vasconcelos, "hay trabajo para toda una editorial durante varias décadas si queremos, ya no competir, por lo menos contener la influencia extranjera. Y solo el gobierno puede emprender obra de esta índole" (Vasconcelos, 2002, p. 86).

Os livros de literatura universal e formação geral deveriam circular não só nas bibliotecas escolares, mas também nas outras modalidades, por serem ferramentas fundamentais para a difusão da cultura. Buscava, especialmente, abarcar o que compreendia serem diferentes formas de expressão cultural do povo mexicano. "En cada caso, la difusión del libro va complementando el programa, desde el taller hasta el aula y el teatro o la sala de exhibiciones estéticas. Ninguna ramo de la cultura escapa a la exigência del material escrito"(Vasconcelos, 2002, p. 87).

A questão fundamental era que livros escolher para compor os acervos. Primeiramente se colocou o que se referia às bibliotecas escolares. Vasconcelos se perguntava o que seria mais adequado para introduzir a criança no mundo da palavra lida; o que não se deveria ler; como delimitar o acesso às obras, considerando os diferentes interesses em relação à idade cronológica; como selecionar os autores a serem lidos, que responderiam a essas questões de cunho pedagógico. Tais problemas advêm da ideia discutida no tópico anterior de que a essa geração estava presente de forma contundente a necessidade de controle e seleção das obras a serem lidas, em especial pela criança.

Vasconcelos entendia que o dilema do que essas crianças deveriam ler seria facilmente resolvido, uma vez que nas bibliotecas escolares os clássicos deveriam estar presentes. A seu ver, tratava-se da manutenção de uma cultura que atravessara a sua geração, permitindo ao povo mexicano uma vivência que outras gerações haviam tido. Citava especificamente quais clássicos que deveriam fazer parte dos acervos, sob o argumento de que, ao lado dos livros populares, deveriam estar os cânones da literatura para o deleite das crianças. ${ }^{18}$

O Departamento de Bellas Artes do México promovia atividades culturais, preconizando uma formação literária das crianças. Uma iniciativa dessa instância educativa em especial foi considerada por Mistral como singular na América Latina. Ela referia-se ao teatro, pensado como uma forma de manter a herança cultural do povo mexicano. Para sustentar o argumento da eminência formativa que a articulação entre as ações do Departamento de Bellas Artes e o de Bibliotecas, narrou, em uma crônica jornalística, a experiência que vivenciara na zona arqueológica da cidade de Teotihuacán, na qual, após as crianças assistirem a uma apresentação teatral que mostrava um tema histórico, poderiam escrever contos e ilustrá-los. Tais contos

18 Vasconcelos considerava bons livros os clássicos de Andersen, Dom Quixote, Ilíada e a Odisséia, e obras dos autores Bello e Sarmento, Alamán e Martí, Montalvo, Rodó e Ugarte, entre outros (Vasconcelos, 2002). 
concorriam a prêmios e, posteriormente, eram encaminhados para publicação. Tratava-se do periódico infantil Pulgarcito, "escrito exclusivamente por los alumnos de la capital, cosa de entretenimiento para ellos; para los maestros, buen motivo semanal de estúdio: solamente en el trabajo libre, el niño se abandona y entrega su verdad" (Mistral, 1926b apud Zegers, 2007, p. 195).

Pulgarcito foi o primeiro periódico infantil editado pela SEP. ${ }^{19} \mathrm{O}$ objetivo era o de integrar professores e alunos das escolas primárias em torno de um ponto: a expressão infantil por meio do desenho. O que enfatizamos nessa publicação é a contemporaneidade da proposta pedagógica que nela se coloca: a produção de um livro a partir do ponto de vista da criança, articulando o desenho à linguagem escrita. Esse periódico ocupou as estantes das bibliotecas infantis mexicanas idealizadas por Mistral, representando uma liberdade temática que matiza a seleção dos livros bons e maus para a criança. Os livros produzidos em situação escolar, por meio de concursos, constituíam-se como um veículo de expressão da visão de mundo das crianças, na qual esses leitores formavam-se mutuamente. De acordo com os estudos de Lombardo García (1997, p. 83), um dos pontos principais dessa publicação destinada ao público infantil é o fato de se tratar de "un espacio para los niños respetado por los adultos. Posiblemente 'Pulgarcito' sea uno de los más bellos ejemplos de publicación periódica para niño".

A concepção de criança que observamos nessa ação do México, incentivada por Mistral, é a de um ser capaz de produzir significados a partir das experiências vivenciadas e de expressá-los, e que a criança merece ser respeitada pelos adultos, entendida como um sujeito de direitos, sendo a literatura infantil por ela produzida um espaço de expressão cultural, ou seja, da forma como percebe o mundo pela escrita e pelo desenho.

Em uma concepção de criança diferente dessa, o personagem Pancholín, que circulava à mesma época na página destinada para crianças no jornal El Universal, trazia a ideia de uma criança ingênua. Isso pôde ser percebido quando Lombardo García (1997, p. 83) analisou que esse personagem despertava encantamento nas crianças que se identificavam com suas "hábiles artimañas, sus êxitos extraordinários en el arte de la trampa y de la burla, que es ingênua y jocunda en sus hazañas de outro tempo".

Identificamos, no caso desse segundo personagem, uma evidência intergeracional, ou seja, um elemento que esteve presente no pensamento iluminista, do qual Mistral foi herdeira: a preocupação de que o adulto, de alguma forma, mantivesse preservada a ingenuidade da criança. De um lado, a descrição de um personagem que não fumava, reforçando a estratégia de formação de um leitor, em uma perspectiva moralizante. Do outro, a presença de passagens que evidenciam que esse personagem poderia subverter a ordem quando se tratasse de preservar, por exemplo, o direito de brincar: "lleva esa enorme pipa de 'detective' para intimidar a los que quiere no ponor se a la realización de alguna de sus travesuras”(Lombardo García, 1997, p. 84).

19 Em Pulgarcito circulavam temas do cotidiano familiar e escolar, como regras de higiene e convivência, excursões além de produções escritas e desenhos livres, inclusive o que hoje definimos como histórias em quadrinhos. Tal perfil foi adotado desde o primeiro número (Lombardo García, 1997). 
A respeito do que não deveria circular nas bibliotecas escolares destinadas às crianças, a reforma mexicana discutia que não seria necessário um método de proibição. $\mathrm{Na}$ opinião de Vasconcelos, o segredo seria o de fomentar o acesso a livros que ele considerava bons, sem enfatizar aqueles que os intelectuais de sua geração consideravam vulgares, que seriam, em sua concepção, os antipatrióticos. Dessa forma, salientava que não havia um método a ser definido pela SEP, o processo de escolha se efetivaria por meio da leitura dos diferentes livros pelos professores, nos quais poderiam especular, de forma sensível, os assuntos neles tratados.

Podemos citar uma das ações colocadas em prática nos espaços destinados à criança no interior das bibliotecas mexicanas, fossem elas nas escolas ou nas bibliotecas públicas: La hora del cuento, realizada nas bibliotecas, era entendida por intelectuais mexicanos como um momento ímpar na formação do leitor. Para Esperanza Velásquez Bringas, ${ }^{20}$ não havia dúvidas de que "esta hora semanária de cuentos en la que se recomiendan los libros del establecimiento y se amplían muchos conocimientos literários e históricos, que los niños han principiado a obtener en la escuela" (Walerstein, 1991, p. 134).

Essa atividade adotava ações pedagógicas consideradas já canônicas, como o manuseio dos livros e a contação de histórias, por exemplo, e inovava por inserir momentos de escuta das impressões literárias. Esse movimento despertava não só o interesse das crianças para as quais a atividade se destinava, mas também o dos adultos que as acompanhavam. Para Mistral, a Hora do Conto era uma forma de proporcionar aos leitores/frequentadores daquele espaço específico de formação o que ela denominava de uma educação moderna. Era a leitura atravessando o cotidiano dos militares, dos professores, dos índios, das mulheres, das crianças, constituindo-se em um momento singular daquele tempo. A chilena percebia que esse movimiento vinha espalhando-se no México ampliando "el esfuerzo ajeno y, sobre todo, a restar tiesura pedagógica a estos actos [...]. Esto viene también del estado de creación que es el natural en esa masa donde se ha producido el músico popular sin técnica y el decorador sin Escuela de Bellas Artes"(Mistral, 1926c apud Zegers, 2007, p. 178).

Mistral defendia que essa atividade literária instruía e educava as crianças, desenvolvendo o imaginário. Desde o tempo em que atuava na educação de crianças pequenas no Chile, instituíra em sua rotina esse momento de contação de histórias. Entendia ser necessário que os profissionais responsáveis por narrar histórias nas salas de leitura ou nas escolas envolvessem as crianças na atividade, deixando-as próximas ao livro que seria apreciado no momento.

20 Esperanza Velásquez Bringas (1899-1980): periodista, maestra e escritora, começou a escrever em um periódico mexicano - El Pueblo - aos 18 anos e a coordenar uma página infantil em outro jornal - El Universal - , no qual usava o pseudônimo Hedda Gabler, sendo uma das pioneiras de entrevistas feitas por mulheres. Combinado a essa atividade, atuava na parte administrativa na Secretaria de Educação Pública, da qual foi chefe do Departamento de Bibliotecas, entre os anos de 1924 e 1928. Em 1929, foi diretora da Biblioteca Nacional. Entrevistou José Vasconcelos, Gabriela Mistral, entre outros. Em 1953, foi agente da Defensoria de Ofícios na Jurisdição Penal. Além disso, fez parte de diversas organizações políticas, como o Partido Socialista (Walerstein, 1991, p. 134). 
Com esse mesmo viés de diálogo com as exigências da modernidade educacional, agora no Brasil, discorremos a seguir sobre o projeto de formação do leitor desenvolvido no Distrito Federal, sob a responsabilidade da educadora brasileira Cecília Meireles, que defendeu uma concepção de criança leitora com base nas práticas de leitura em uma biblioteca infantil.

\section{O CENTRO CULTURAL PAVILHÃO MOURISCO: ${ }^{21}$ UM PROJETO DE FORMAÇÃO DO LEITOR}

O Centro Cultural Pavilhão Mourisco foi a concretização do ideal de escola defendido por Cecília Meireles ao congregar todos os aspectos que tal instituição deveria ter, conforme defendeu em crônicas, cartas e conferências. Seu pensamento era criar um espaço para formação integral da criança, que, para ela, dava-se por meio da cultura, da arte e também do livro.

A preocupação com a formação do leitor em uma perspectiva ampla inspirou a organização do Centro Cultural Pavilhão Mourisco. Uma das ações da intelectual Cecília Meireles foi explorar os dados obtidos em um inquérito que descreveu em carta a Azevedo (Lamego, 1996). Nesse inquérito constavam os livros e autores preferidos de crianças dos 7 a 14 anos, em vinte e quatro escolas do Distrito Federal (Rio de Janeiro), além de informações sobre as condições das bibliotecas escolares municipais. O referido inquérito foi publicado no ano de 1934, pelo Instituto de Pesquisas Educacionais. ${ }^{22}$

A escolha para organizar o centro cultural por meio de um inquérito às crianças, inovadora para a época, confere a elas um estatuto de sujeito, entendendo-as como protagonistas do seu próprio processo de formação como leitoras. Conquanto os livros fossem escolhas do adulto, tanto no que diz respeito ao seu conteúdo quanto na seleção, o fato é que tal iniciativa significava abrir espaço para entender a perspectiva da criança em relação à leitura.

Meireles atuou na organização do centro cultural durante a gestão de Anísio Teixeira no Distrito Federal, período no qual houve investimento em bibliotecas infantis. Para Anísio Teixeira, "esse espaço teria que ser uma espécie de casa da criança, um verdadeiro órgão de pesquisa”, no qual resultados benéficos pudessem ser percebidos no futuro dos frequentadores (Pimenta, 2001, p. 93).

Para a elaboração do projeto dessa biblioteca, contou com o auxílio do embaixador mexicano Alfonso Reyes e das estagiárias Isaura Costas Nunes, responsável pela organização do inquérito pedagógico, e Graziella Passos, que respondeu pela

21 Sobre o Centro Cultural Pavilhão Mourisco, ver Pimenta (2001) e o decreto n. 4.387, de 8 de setembro de 1933, que fixava instruções para regularizar seu funcionamento.

22 Os objetivos do inquérito eram "saber se o aluno gostava de ler e quantos livros, mais ou menos, tinha lido; saber de que tipo de livros mais gostava e de quais não gostava e se tinha vontade de ler algum livro; saber se o aluno achava se valia a pena ler e onde preferia ler, se em casa ou na escola; perguntar se preferia livros em prosa ou em verso, e quais eram os livros mais interessantes, se os de histórias, de viagens, de ciências, de aventuras, romances ou fábulas, saber de qual autor mais gostava e, dos autores nacionais, qual o que mais the agradava" (Pimenta, 2001, p. 100). 
confecção do álbum de recortes e da Gazetinha - jornal mural de informação diária e duas atividades de cunho pedagógico, parte das preocupações de Meireles com a formação do leitor.

O espaço de cultura tinha a função social de, em um primeiro plano, divulgar os livros e conservar o acervo. Simultaneamente a essa cultura de difusão e conservação dos bons livros, Meireles implementou práticas de leitura pública voltadas para as "necessidades de instrução" (Chartier e Hébrard, 1995, p. 141), como ocorrera com a publicação dos catálogos da Gazetinha. Representava uma opção que era contrária à defesa parisiense de que tais formas de divulgação do conhecimento impressão de catálogos informativos - representavam "uma confissão tingida de impotência" (Chartier e Hébrard, 1995, p. 141).

Tratava-se de uma biblioteca infantil em que "Cecília Meireles pode desenvolver sua criatividade e seu empenho em favor da literatura infantil" (Pimenta, 2001, p. 7). Por extrapolar os objetivos de uma biblioteca, pois unia atividades como música, cinema, cartografia e jogos, transformou-se em um centro cultural infantil, perspectiva também inovadora para a época.

$\mathrm{O}$ centro, que ficava em um prédio de arquitetura neopersa, com traços mouriscos, apresentava, no próprio estilo e decoração, a cultura e a arte literária. A construção final contou com sete pavimentos e duas torres com cúpulas de cobre, com varandas formadas por longos corredores e diferentes ambientes, conforme Figura 4, que mostram um pouco desse edifício que já não existe mais.

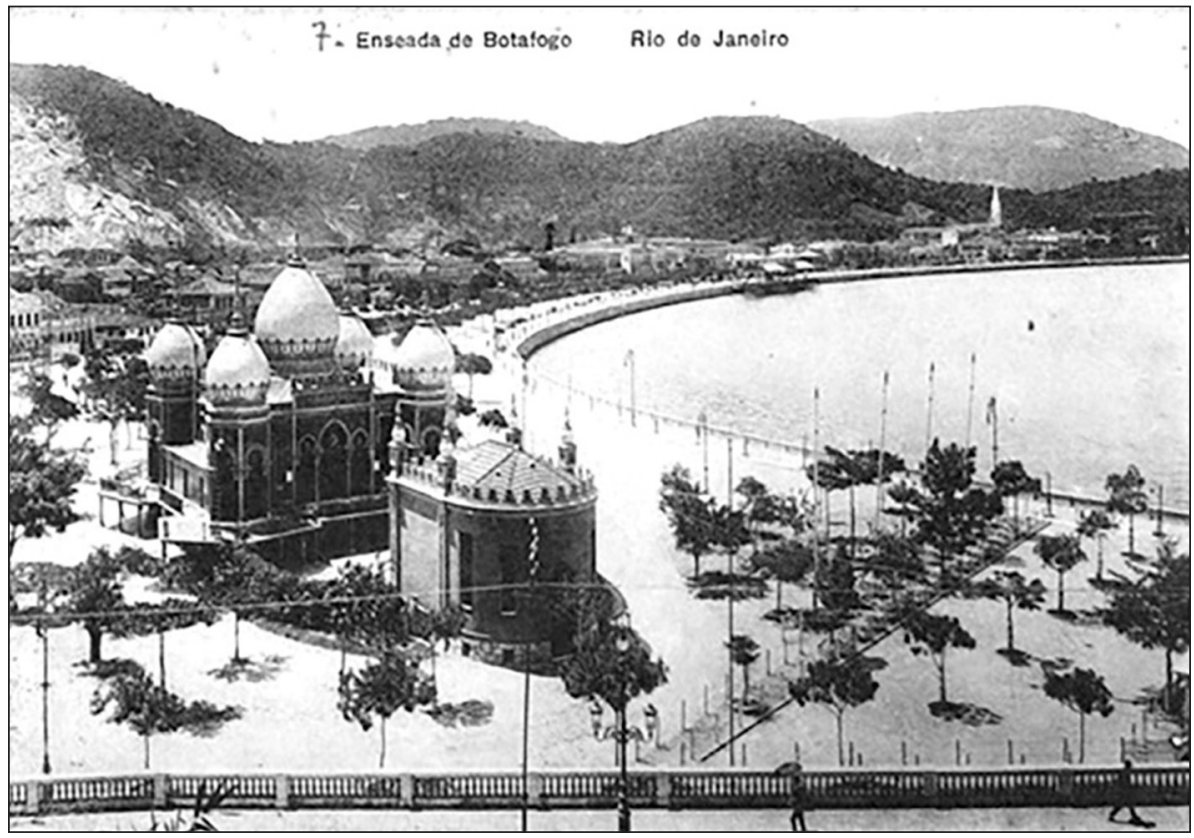

Figura 4 - Centro Cultural Pavilhão Mourisco

Fonte: <http://1.bp.blogspot.com/-EeQHSYfQ8j4/U6PIx8P-huI/AAAAAAAAAKk/FG2eBHCjHgc/s1600/BN_A_ Ribeiro_Enseada_Botafogo.jpg >.Acesso em: 10 dez. 2012. 
O resultado do empenho na organização desse espaço físico, assim como o cuidado em aproximar o leitor do livro, gerou interesse das crianças que frequentavam esse espaço cultural, conforme pode ser constatado na leitura dos estudos sobre os livros de registros desse centro. ${ }^{23}$ Estudantes de escolas públicas, após o término das aulas, buscavam esse local a fim de desenvolver atividades estéticas e artísticas, uma vez que a biblioteca funcionava no turno da manhã e da tarde.

A sala de leitura encantava os visitantes, possuía vidraças coloridas, mesas alegres com vasos de barro com flores, estantes por toda sala, nas quais os livros encontravam-se organizados de forma peculiar, não enfileirados. O objetivo era que o leitor sentisse vontade de pegá-los para folheá-los ou lê-los em algum lugar do próprio centro. Influenciado pela estrutura física do lugar, Correia Dias "compôs um cenário das Mil e Uma Noites, que proporcionava aos frequentadores uma atmosfera de encantamento e fantasia" (Pimenta, 2001, p. 97). No teatro, havia no palco uma placa de metal com a inscrição Caverna Maravilhosa e uma lâmpada como a de Aladim ao fundo. A sala de música e cinema tinha uma decoração de fundo de mar.

Para atrair o interesse das crianças, tanto as salas de leitura como as destinadas a outras atividades realizadas no Pavilhão Mourisco foram pensadas em minúcias tanto no aspecto físico, como já discutido, como no estrutural, tendo havido toda uma preocupação em relação a seu funcionamento e instalação. Tal organização foi publicada em documento assinado por Anísio Teixeira, informando as seções que formariam o então centro cultural. Entre tais seções estavam a de livros, de gravura, de cartografia, de recortes, de selos e moedas, de música, além daquelas ligadas a atividades artísticas destinadas ao público infantil, de propaganda e publicidade, de observações e pesquisas. ${ }^{24}$

Entre as seções do centro cultural, destacamos aquela destinada às atividades artísticas e literárias voltadas, em especial, às crianças, pela qual Meireles respondia

23 O número de inscrições confirmava o entusiasmo das crianças com a biblioteca, que, com apenas dez dias de funcionamento, já absorvia setenta a três inscrições com mais de trinta consultas diárias. Ao completar um trimestre, a biblioteca abrigava duzentos leitores e, no final do ano de 1937, já alcançava o número de um mil e quinhentos leitores assíduos. Às crianças era oportunizado o acesso à arte e à cultura sem a necessidade do acompanhamento e interferência de seus responsáveis. Elas preenchiam uma ficha, recebiam uma numeração, selecionando os materiais de interesse, podendo fazer empréstimo de até um livro (Pimenta, 2001).

24 A primeira seção, a biblioteca propriamente dita, possuía inicialmente 720 obras (498 livros didáticos - de leitura, compêndios, manuais etc.; 222 obras literárias - em prosa e verso, literatura infantil tanto de autores nacionais quanto traduzidas para o português), entre as quais 310 foram compradas e 391 doadas por terceiros e pela Biblioteca Central de Educação (BCE). A segunda, a de gravuras, contava com 2.781 unidades, com toda a documentação gráfica relativa ao Brasil - história, arte, ciência trabalho etc. A de cartografia, a terceira, contava com globos, mapas do Brasil e dos estados, do mundo, da América e da cidade do Rio de Janeiro, plantas topográficas, bandeiras etc. A quarta, a de recortes, era composta de 23 álbuns (similares a uma enciclopédia, que versava sobre assuntos distintos) e responsável pela edição de $A$ Gazetinha. A quinta, com coleções de selos e moedas, devidamente estudadas e catalogadas. A de música e cinema possuía um aparelho Pathé Baby, rádio, radiola e discos. A sétima compunha atividades artísticas, como a Hora do Conto, arte dramática etc. 
pessoalmente. Um momento da rotina dessa sala, que se constituía como algo caro à educadora, era a Hora do Conto que, sempre que possível, tinha a presença de escritores.

No centro eram desenvolvidas ainda atividades pedagógicas complementares à escola e outras destinadas à formação do professor, com uma seção que produzia um jornal mural que se constituiu como meio de divulgação de pesquisas e estudos dos docentes.

Para composições das seções descritas, parte das obras era proveniente de doações da própria Meireles, de educadores e de algumas editoras, tendo em vista que a verba era limitada e havia carência de livros que fizessem a vez de enciclopédias infantis, o que foi resolvido também por meio das Gazetinhas, conforme dito anteriormente..$^{25}$ Meireles idealizou vários álbuns de recortes de revistas, jornais e folhetos de propagandas, que continuaram a ser confeccionados, mesmo após a inauguração do centro, a partir dos materiais que eram doados constantemente à biblioteca.

\section{A LEITURA PÚBLICA DEDICADA À CRIANÇA: COMPARANDO PERCURSOS DE MISTRAL E MEIRELES}

O cuidado com a literatura infantil foi a preocupação maior de Gabriela Mistral e Cecília Meireles, fundamentando seus comentários e suas argumentações sobre o fato de que escrever para criança significava instigá-la à leitura por fruição, sensibilizada por outras manifestações artísticas. Para esse fim, trabalharam na construção de espaços específicos para leitores mirins.

Esses percursos apontam para uma compreensão da temporalidade vivida por Mistral e por Meireles como um momento de busca pela legitimação de uma concepção de infância pautada no respeito à criança, como um sujeito situado histórica e geograficamente em um espaço de diversidades. Discursos educacionais das duas intelectuais apontam para a relevância da excelência literária, que só poderia ser alcançada a partir da apreciação das próprias crianças. De um lado, criticavam veementemente as histórias fúteis, debochadas ou de caráter moralizante; de outro, evidenciavam a riqueza literária de obras que colocavam a criança como foco principal e a valorização de manifestações culturais das próprias crianças. É possível perceber nessas posturas o rompimento com a concepção única de infância a ser moldada, alicerçada no pressuposto de que as crianças se desenvolvem linearmente, de forma progressiva.

Em que medida as atuações de ambas as intelectuais se diferenciavam da tradição de formação do leitor que selecionava a leitura a que as crianças teriam acesso, legatária do pensamento iluminista? Trazem de novo a ideia de ampliar essas ofertas às classes populares e de incorporar a elas produções das próprias crianças. As duas educadoras participam dessa revolução intelectual que possibilitou a defesa pela leitura pública; coadunaram-se com essa revolução, quando reconheceram a importância da leitura em um projeto moderno de nação; inovaram, todavia, quando defenderam a ampliação do acesso à leitura não apenas nas escolas e pelas bibliotecas,

25 Sobre detalhamentos de doação, ver Pimenta (2001). 
mas em outras instâncias sociais que aproximassem as crianças também da cultura do campo, no caso da intelectual chilena, e de outras manifestações artísticas, como a música, a dança, o teatro, no caso da brasileira.

As bibliotecas materializaram um projeto em especial: aquele no qual ao leitor fosse possibilitado o acesso ao livro, entendido como um bem cultural, que aproximaria realidades e romperia fronteiras temporais, possibilitando ver pelos olhos do outro, interpretando de forma singular, o mundo. Esse leitor se formaria para (des)formar o mundo. A produção e circulação de livros, fundamentada em uma concepção de literatura infantil que aproximasse a criança da leitura, criaria condições para que os leitores pudessem interagir com esses livros, naqueles espaços, rompendo as fronteiras que a própria materialidade da biblioteca colocava. Tanto Mistral quanto Meireles entendiam a Hora do Conto como uma dessas condições que, no plano pedagógico, representa um traço do novo da modernidade educacional, reconhecida por Mistral como uma inovação singular. Inovação esta sustentada pela rede de referenciabilidades que vieram instituindo no decorrer de suas atuações nos campos literário, jornalístico e educacional. Ambas as intelectuais viam a biblioteca como um espaço propício à divulgação dos livros, sendo a contação de histórias um momento significativo para a viabilização do projeto de formação do leitor.

Defensoras da leitura pública, Mistral e Meireles acreditavam que tal prática poderia contribuir para a formação integral dos sujeitos. Atuaram no projeto unificador de formação da criança leitora que congregava diferentes realidades sociais, entendendo ser o "bom livro" um meio propício a esse projeto oriundo da modernidade educacional. Esse bem cultural, a despeito de ter nas bibliotecas escolares um local específico para sua circulação, poderia formar leitores à medida que as histórias nele contidas pudessem ser contadas nas imagens do cinema, do teatro e de outras instâncias sociais. O livro poderia sair das prateleiras e ganhar campos, jardins, bibliotecas públicas com espaços especialmente pensados para a criança leitora. Era preciso, no tempo em que atuaram em projetos de formação do leitor, fundar escolas e, ao mesmo tempo, desenvolver e divulgar ações pedagógicas que pudessem formar as crianças.

As atuações de Gabriela Mistral e Cecília Meireles em múltiplas frentes convergiram na defesa de ideais educacionais voltados à formação da criança leitora. Todavia, os argumentos em que se pautavam na defesa de uma educação popular apresentam convergências e divergências. Convergem na defesa da escola numa perspectiva antropológica, uma vez que ambas entendiam ser função dessa instituição oportunizar acesso a experiências estéticas, que tanto poderiam advir do saber do povo quanto do conhecimento acumulado pelas gerações anteriores. As divergências colocam-se quando Mistral entende a escola como uma das instâncias de formação do leitor e Meireles a reconhece como a principal instância formadora. Para a educadora chilena, seriam necessários investimentos públicos e da sociedade em esferas ampliadas de formação; para a brasileira, esses recursos deveriam estar centrados na instituição escola.

A contemporaneidade do pensamento dessas duas intelectuais manifesta-se na relevância do projeto de leitura pública que efetivaram e que não teve continuidade. A despeito de ações políticas que preconizaram o acesso ao livro, tanto no 
México quanto no Brasil, constata-se que a maior parte das bibliotecas organizadas na gestão de Vasconcelos, assim como na de Anísio, enfrentou problemas de natureza econômica e política. No caso do México, houve precarização de investimentos para manutenção e ampliação de acervos; no do Brasil, foram extintas algumas das bibliotecas fundadas na década de 1930 .

Formar a criança leitora ainda desafia educadores e políticas públicas. As experiências do Brasil e do México, aqui apresentadas, podem apontar lacunas ainda presentes nessas políticas. Se por um lado ampliamos nossas ações no intuito de trazer de forma mais contundente a experiência da criança e a qualidade estética como critérios para a seleção dos acervos hoje disponibilizados às crianças e aos professores por iniciativas governamentais de distribuição de obras às escolas, por outro ainda precisamos atuar em direção à formação dos mediadores da relação da criança com o livro. Esses mediadores são não apenas os professores, mas também as famílias, de modo geral.

No contexto brasileiro, em especial, a formação do professor leitor tem sido objeto de atenção da pesquisa acadêmica, que aponta o necessário investimento na dimensão estética dessa formação para que os docentes disponham de condições de abordar a leitura na escola como prática cultural, objeto de fruição e capaz de ampliar horizontes, para além de uma perspectiva mecanicista do seu ensino.

No que concerne às famílias, políticas de formação de leitores centradas exclusivamente no papel da escola nessa formação ainda apresentam uma lacuna no que concerne à formação de uma sociedade leitora, uma vez que deixam de fora a experiência das comunidades com o livro, objeto ainda de difícil acesso às camadas populares. Nesse sentido, há muito o que aprender com o projeto de constituição das bibliotecas populares no México, especialmente por sua ênfase na importância de levar os livros às comunidades, ao mesmo tempo em que se investe no registro das experiências culturais dessas comunidades em obras representativas de tais experiências.

Nesse sentido, e pelo exposto até aqui, a pesquisa apresentada aponta o caráter de inacabamento do projeto da modernidade educacional que deu origem às redes de referenciabilidades instituídas por Mistral e Meireles, no que concerne ao ideal de acesso não apenas à escola, mas à cultura pelas classes populares e ao papel do estado em garantir esse acesso.

\section{REFERÊNCIAS}

Azevedo, F. A reconstrução educacional no Brasil ao povo e ao governo: Manifesto dos Pioneiros da Educação Nova. São Paulo: Cia. Editora Nacional, 1932.

Chartier, A.-M.; Hébrard,J. Discursos sobre a leitura: 1880-1980. São Paulo: Editora Ática, 1995.

Distrito Federal. Decreto n. 4.387, de 8 de setembro de 1933. Consolida a organização técnica e administrativa do aparelho de direção do sistema educacional, instituindo o Departamento de Educação do Distrito Federal. In: PAgani, I.; Velloso, G. P.; Dias, A. Coleção de Leis Municipais Vigentes - 1932 a 1935. v. 5. Rio de Janeiro: Oficinas Gráficas do Jornal do Brasil, 1937. p. 427-436. 
Fell, C. José Vasconcelos los años del águila: educación, cultura e iberoamericanismo en el México post revolucionario. México: Universidad Nacional Autonoma de México, 1989. Ferreira, R. V.J. Entre leitores, bibliotecas, campos e jardins: Gabriela Mistral e Cecília Meireles em projetos de educação popular no México (1920) e Brasil (1930). 328f. Tese (Doutorado em Educação) — Universidade Federal de Juiz de Fora, Juiz de Fora, 2014. Fernandes, H. M. Cecília Meireles e a lírica pedagógica em "Criança meu amor" (1924). 192f. Dissertação (Mestrado em Educação) - Universidade Federal do Rio Grande do Norte, Natal, 2008.

Gomes, A. C. Essa gente do Rio... os intelectuais cariocas e o Modernismo. Estudos Históricos, Rio de Janeiro: FGV, v. 6, n. 11, p. 62-77, 1993.

Lamego, V. A farpa na lira: Cecília Meireles na Revolução de 30. Rio de Janeiro: Record, 1996.

Lôво, Y. Cecília Meireles. Recife: Massangana, 2010.

Lombardo García, I. Pulgarcito y la educación estética. Chicomoztoc, Cidade do México, v. 6, p. 79-126, 1997.

Meireles, C. A infância. Diário de Notícias, Rio de Janeiro, p. 7, 20 dez. 1930. Arquivo do Acervo da Biblioteca Nacional do Brasil.

. Sobre um discurso de Alfonso Reyes. Diário de Notícias, Rio de Janeiro, p. 6, 16 abr. 1932a. Arquivo do Acervo da Biblioteca Nacional do Brasil.

. Livro para crianças. Diário de Notícias, Rio de Janeiro, p. 6, 26 abril 1932b. Arquivo do Acervo da Biblioteca Nacional do Brasil.

México. Lecturas clásicas para niños. Ciudad de México: Departamento Editorial de la Secretaría de Educación, 1924a. 1 v.

. Lecturas clásicas para niños. Ciudad de México: Departamento Editorial de la Secretaría de Educación, 1924b. 2 v.

Mistral, G. La fiesta del árbol: las colônias rurales - uma plaza de juegos para niños. México, 17 fev. 1924. In: Zegers, P. P. (Comp.). Gabriela y México. 1. ed. São Paulo: Ril Editores, 2007. p. 140.

. Dos períodos. El París, jun./jul. 1926a. In: Zegers, P. P. (Comp.). Gabriela y México. 1. ed. São Paulo: Ril Editores, 2007. p. 175.

. Teatro índio. El París, jun./jul. 1926b. In: Zegers, P. P. (Comp.). Gabriela y México. 1. ed. São Paulo: Ril Editores, 2007.p. 195.

. La hora del cuento. El París, jun./jul.1926c. In: Zegers, P.P.(Comp.). Gabriela y México. 1. ed. São Paulo: Ril Editores, 2007. p. 178.

. Inauguración de una biblioteca veracruzana. Política y Espíritu, n. 44-45, jan./ abr. 1950. In: Zegers, P. P. (Comp.). Gabriela y México. 1. ed. São Paulo: Ril Editores, 2007.p. 316.

Mistral, G. Páginas en prosa. Buenos Aires: Kapelusz, 1962.

Nunes, C. Dilemas da modernidade latino-americana: autoria feminina e discurso pedagógico. In: Bencostta, M. L. A. (Org.). Culturas escolares, saberes e práticas educativas: itinerários históricos. São Paulo: Cortez, 2007. p. 401-422. 
Nunes, C. (Des)encantos da modernidade pedagógica: uma releitura das trajetórias e da obra de Cecília Meireles (1901-1964) e Gabriela Mistral (1889-1957). Niterói: Relatório de Pesquisa, maio/jun. 2009.

Pimenta, J. S. Fora do outono certo nem as aspiraçóes amadurecem: Cecília Meireles e a criação da Biblioteca Infantil do Pavilhão Mourisco (1934-1937). 2001. $167 f$. Dissertação (Mestrado em Educação) - Pontifícia Universidade Católica, Rio de Janeiro, 2001.

Ricoeur, P. A crítica e a convicção. Lisboa: Edições 70, 1995. . A memória, a história, o esquecimento. Campinas: UNICAMP, 2007. . Tempo e narrativa. Campinas: Papirus, 2012. t. III.

Rocha, M. B. M. O ensino elementar no Decreto Leôncio de Carvalho: "visão de mundo" herdada pelo tempo republicano? Revista Brasileira de Educação, Rio de Janeiro: ANPEd; Campinas: Autores Associados, v. 15, n. 43, p. 126-147, 2010.

Schirewer, J. Sistema mundial y redes de interrelación: la internacionalización de la educación y el papel de la investigación comparada. Revista Nueva Epoca, Bogota: Universidad Libre, v. 1, n.1, p. 21-58, jan./jun. 1997.

Vasconcelos, J. De Robinsón a Odiseo: pedagogia estructurativa (1935). Monterrey: Cámara de Senadores, 2002.

Walerstein, L. S. Vasconcelos el hombre del libro: la época de oro de las bibliotecas. México: Universidad Nacional Autónoma de México, 1991.

Zegers, B. P. P. (Comp.). Recopilación de la obra mistraliana: 1902-1922. São Paulo: Ril Editores, 2002. . (Comp.). Gabriela y México. São Paulo: Ril Editores, 2007.

\section{SOBRE AS AUTORAS}

Rosângela Veiga Júlio Ferreira é doutora em educação pela Universidade Federal de Juiz de Fora (UFJF). Professora do Colégio de Aplicação João XXIII/UFJF.

E-mail: rosangelaveiga.ferreira@uff.edu.br

Hilda Aparecida Linhares da Silva Micarello é doutora em educação pela Pontifícia Universidade Católica do Rio de Janeiro (PUC-Rio). Professora da Universidade Federal de Juiz de Fora (UFJF). E-mail: hilda.micarello@uab.uff.br

Recebido em 31 de agosto de 2015 Aprovado em 22 de fevereiro de 2016 